\title{
Physico chemical parameters of water of some selected areas of Tamirabarani river, Tirunelveli, Tamilnadu
}

\author{
O.V.Sheebha Malar ${ }^{1}$, Dr.P.Kokila ${ }^{2}$, Dr.C.Isac Sobana Raj $^{3}$ \\ ${ }^{1}$ Research Scholar, Manonmaniam Sundaranar University, \\ Tirunelveli, Tamil Nadu -627012, India. \\ ${ }^{2}$ Department of Chemistry, Vivekananda College, Agasteeswaram, \\ Kanyakumari, Tamil Nadu-629701, India. \\ ${ }^{3}$ Department of Chemistry and Research, Nesamony Memorial Christian College, \\ Marthandam, Tamil Nadu-629165, India.
}

\begin{abstract}
:
In Tirunelveli and Thoothukudi districts Tamirabarani River is flowing continuously for $128 \mathrm{~km}$ and drains into the Bay of Bengal at Punnaikayal village. In this present study, physico chemical parameters of some selected areas of Tamirabarani River water of Tirunelveli, was analyzed from 2013 to 2016. Seven sampling points were selected and the water samples were examined. The parameters such as chloride, sulphate, total alkalinity, calcium, magnesium and hardness were analyzed. Paper industrial waste, textile pollutants and temple waste are added to this point. These are the main sources of pollutants of Tamirabarani River. Tamirabarani is a main source of water supply to many towns which include Tirunelveli Corporation. In Tirunelveli corporation area the drinking water is not treated properly. Entire flow on the river has turbidity. The main aim of this paper is to analyze the various pollutants of Tamirabarani River by selecting seven different sites.
\end{abstract}

Keywords: Tamirabarani River, pollutants, chloride, Sulphate, total alkalinity, calcium, magnesium and hardness.

\section{Introduction}

In this world today all human beings are affected by one of the major problem "Environmental Pollution". Pollution has now become an individual threat to the very existence of mankind on this earth. It is now a major challenge of our times. Olden times man has been disturbing the balance of nature for comfort, wealth and ego but now nature has started to disturb the balance of nature. The endurance of human beings on this planet is based on the principle of Le-Chatelier which states that "whenever any system at equilibrium is subjected to stress, it will react in such a way so as to relieve that stress". The principle of Le-Chatelier thus operates as a conservative force to return the stressed system to an earlier less stressed one [7].

Water is essential for every living organism and is one of the most valuable natural resources on this earth. Human life is tied directly or indirectly to fresh water source such as lakes, rivers and estuaries. Human beings as well as other global and adequate life forms are sensitive to changes in the quality of the fresh water supply. Changes in quality of water such as chloride, sulphate, total alkalinity, calcium, magnesium and hardness are affect the mortality of aquatic life. The distinctiveness of both natural weathering process and anthropogenic activities can have a significant impact on water quality. Rain fall tends to dissolve and carry away minerals and contaminants found in the soil and the atmosphere [9].

Human as well as natural phenomena are responsible for bringing disturbances in the river system. People mostly depend on water for agricultural and domestic purposes. But with rapid population growth and urbanization, different activities like unplanned building and encroachment, clearing of riparian vegetation along the river banks, 
disposal of waste materials in river are commonly observed in rivers [4].

Rivers are important in maintaining the soil fertility, forest and wildlife conservation activities. Therefore, river water quality monitoring program is necessary in order to safeguard public health as well as to safeguard the ecosystem [8]. Water pollution due to anthropogenic activities at river Tamirabarani has been reported in earlier studies [5], [11]- [16], [18].

\section{Tamirabarani river}

The Tamirabarani River (Porunai) is a only perennial river in south India that originates from the Agastyar koodam peak of Pothigai hills of the Western Ghats, above Papanasam in the Ambasamudram taluk. It flows through Tirunelveli and Tuticorin districts of the Tamil Nadu state of southern India into the Gulf of Mannar. It has many ancient temples along its banks. Tirunelveli district is situated between $8.05^{\circ}$ and $9.30^{\circ}$ of the northern latitude, and between $77.05^{\circ}$ and $78.25^{\circ}$ of the eastern longitude [17].Majority of the people of Tirunelveli are Hindus and worship different gods. Hinduism is one of the world's oldest religions and has over 900 million adherents. It is not a single doctrine and has no single founder or teacher.

\section{Need for present study}

Poor water quality may be caused by low water flow, municipal effluents and industrial discharges [10]. The Tamirabarani is a symbol of Tamil culture and civilization and an identity of the far south of India. The main source of water for the districts of Tirunelveli and Tuticorin is the only perennial river in the region and it runs through the heart of the cities. Thousands of people depend on the river for their routine activities and for satisfying their basic needs. Mixing of sewage, industrial effluents, dumping solid waste etc into the river is a worrying aspect. Local complaints and news paper reports on the cleanliness less of the river have made the subject a major issue to discuss. Although Tirunelveli authorities have taken steps to evict encroachments near the Tamirabarani river encroachments have not yet been removed from other areas and sewage being still let in to the river.
This study was carried out from 2013 to 2016 and water samples were collected in the bottle after rinsing it in the same water 3 or 4 times. The sample was collected from seven sites of the river from centre of the width after avoiding the floating depress on the top. After the collection the bottle was tightly closed, marked and labeled. Seven different sites are $\left(\mathrm{S}_{1}\right)$ Vickramasingapuram, $\left(\mathrm{S}_{2}\right)$ Ambasamudram, $\left(\mathrm{S}_{3}\right)$ Cheranmahadevi, $\left(\mathrm{S}_{4}\right)$ Thirupudaimarthur, $\left(\mathrm{S}_{5}\right) \quad$ Tirunelveli, $\quad\left(\mathrm{S}_{6}\right)$ Muruppanadu and $\left(S_{7}\right)$ Authoor surrounding the Tamirabarani River. All parameters were analysed in the laboratory by using standard methods, APHA 2005 [21].

\section{Results and Discussion}

According to the studied parameters, the water quality of the river is classified based on the national [2] and international [19] water quality criteria. The results of water quality parameters of water samples from seven stations in Tamirabarani estuarine are present in tables (1-6).

\subsection{Chloride}

Chloride occurs naturally in all types of water with a very low concentration. Chlorides are important in detecting the contamination of surface water by waste water. In general, high evaporation tends to increase the Chloride and Salinity at the root zone of irrigated plants, making it difficult for crops to take up water due to Osmotic pressure difference between the water outside the plants and within the plant cells.

Table 1: Variation of chloride in different sites at different seasons

\begin{tabular}{|c|c|c|c|c|c|c|c|c|}
\hline Year & Season & S1 & S2 & S3 & S4 & S5 & S6 & S7 \\
\hline \multirow{3}{*}{2013} & Winter & 22 & 20.3 & 60 & 135 & 134 & 22 & 35 \\
\cline { 2 - 9 } & Summer & 20 & 22 & 55 & 140 & 130 & 22 & 32 \\
\cline { 2 - 9 } & Rainy & 18 & 23.5 & 65 & 145 & 132 & 31 & 31 \\
\hline \multirow{3}{*}{2014} & Winter & 17 & 21 & 65 & 152 & 132 & 25 & 35 \\
\cline { 2 - 9 } & Summer & 18 & 22 & 255 & 244.5 & 135 & 50 & 36 \\
\cline { 2 - 9 } & Rainy & 20 & 21.5 & 70 & 144 & 130 & 45 & 32 \\
\hline \multirow{3}{*}{2015} & Winter & 64 & 40 & 175 & 28 & 50 & 50 & 24 \\
\cline { 2 - 9 } & Summer & 61 & 45 & 208 & 30.6 & 56 & 45 & 23 \\
\cline { 2 - 9 } & rainy & 70 & 50 & 290 & 32 & 62 & 49 & 25 \\
\hline \multirow{3}{*}{2016} & winter & 65 & 42 & 279 & 29.2 & 51 & 45 & 24 \\
\cline { 2 - 9 } & summer & 65 & 44 & 251 & 257 & 52 & 47 & 29 \\
\cline { 2 - 9 } & rainy & 62 & 40 & 283 & 32.5 & 62 & 46 & 24 \\
\hline
\end{tabular}

\section{Materials and methods}




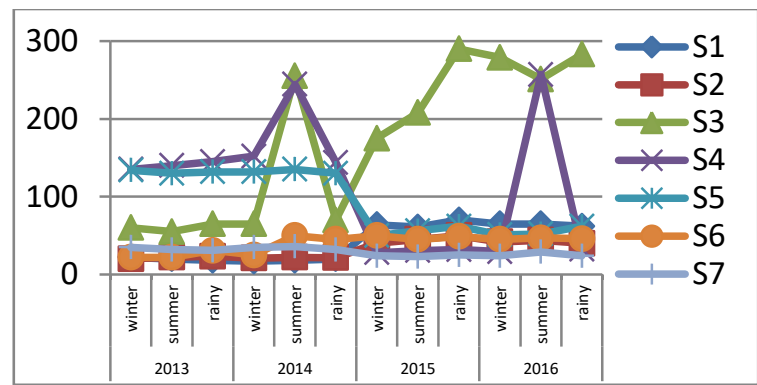

Figure 1: Variation of Chloride with time in different sites at different seasons

For this reason, chloride and total salinity concentration at or below the drinking water standards are normally specified for waters used to irrigate salt sensitive crops. However, in the study area there is no significant change in Chloride concentration and it ranged from 17 to $290 \mathrm{mg} / \mathrm{l}$. Chloride which have been associated with pollution as an index are found below the permissible value set at $250 \mathrm{mg} / \mathrm{l}$ in most of the study area. Chloride in excess (> $250 \mathrm{mg} / \mathrm{l})$ imparts a salty taste to water and people who are not accustomed to high chlorides can be subjected to laxative effects. The chloride content in the rainy season of the surface water samples of $\mathrm{S}_{3}$ showed higher than the prescribed limit may be due to the presence of septic tanks. It has been reported that more than 40 septic tanks for every 2.6 sq. $\mathrm{km}$ area may begin to influence adversely water quality [20]. Ironically, hundreds of septic tanks were existing in the (S3) Cheranmahadevi area.

Chloride ion usually enhances corrosive properties of water especially when such water is in contact with stainless steel materials. It also affects taste of water. Chloride ion may be present in water in combination with one or more of the cations of calcium, magnesium, iron or sodium. Chlorides of these minerals are present in water because of their high solubility in water. Chloride was estimated by Mohr's titration method. Excessive presence of chloride in water indicates sewage pollution. 12 to $306 \mathrm{mg} / \mathrm{L}$ of $\mathrm{Cl}^{-}$is seen in aquifer water and in tube or bore well it shows a variation from 0.1 to 2.24 $\mathrm{mg} / \mathrm{L}$. In pond water ranges from 1.1 to $9.8 \mathrm{mg} / \mathrm{L}$.

\subsection{Sulphate}

The permissible and excessive concentration of sulphate in drinking water is 200 and $400 \mathrm{mg} / \mathrm{l}$, respectively, according to WHO. Sulphate is sometimes reduced by microorganisms and therefore causes foul odour.
Table 2: Variation of sulphate in different sites at different seasons

\begin{tabular}{|c|l|c|c|c|c|c|c|c|}
\hline year & Season & S1 & S2 & S3 & S4 & S5 & S6 & S7 \\
\hline \multirow{3}{*}{2013} & Winter & 102 & 158.2 & 190 & 70 & 40 & 144 & 25 \\
\cline { 2 - 9 } & Summer & 113 & 160.8 & 195 & 85 & 45 & 146 & 22 \\
\cline { 2 - 9 } & ainy & 115 & 167 & 170 & 90 & 42 & 136 & 24 \\
\hline \multirow{3}{*}{2014} & Winter & 109 & 168 & 172 & 75 & 42 & 100 & 25 \\
\cline { 2 - 9 } & Summer & 110 & 161 & 197 & 184 & 41 & 170 & 26 \\
\cline { 2 - 9 } & Rainy & 117 & 172 & 168 & 84 & 49 & 156 & 26 \\
\hline \multirow{3}{*}{2015} & Winter & 172 & 157 & 43.9 & 138 & 120 & 30 & 95 \\
\cline { 2 - 9 } & Summer & 176 & 158 & 41 & 149 & 115 & 29 & 95 \\
\cline { 2 - 9 } & Rainy & 168 & 163 & 52 & 145.6 & 140 & 28 & 96 \\
\hline \multirow{3}{*}{2016} & Winter & 173 & 150.2 & 45 & 142 & 152 & 27 & 98 \\
\cline { 2 - 4 } & Summer & 175 & 154 & 146 & 148 & 145 & 26 & 95 \\
\cline { 2 - 5 } & 178 & 153 & 56 & 147 & 123 & 28 & 92 \\
\hline & Rain & & & & & \\
\hline
\end{tabular}

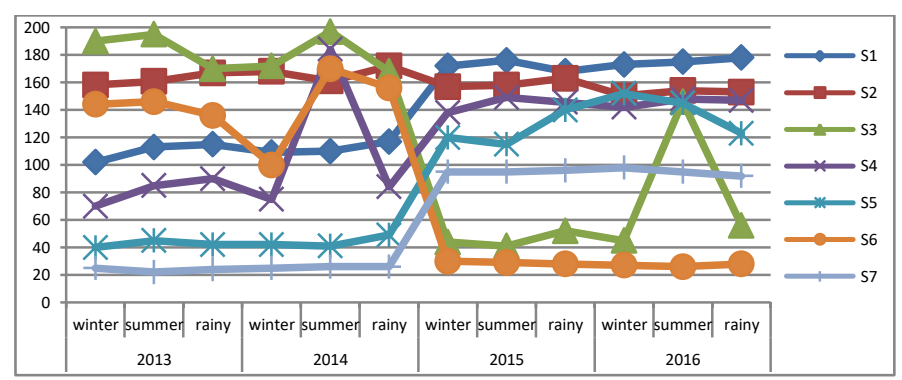

Figure 2: Variation of Sulphate with time in different sites at different seasons

The concentration of sulphate ranged between 22 $\mathrm{mg} / \mathrm{l}$ to $195 \mathrm{mg} / \mathrm{l}$ in the surface water of the study area. Sulphates occur in water due to leaching from sulphate mineral and oxidation of sulphides. Sulphates are associated generally with calcium, magnesium and sodium ions. Sulphate in drinking water causes a laxative effect and gastrointestinal irritation leads to scale formation in boilers. It leads to corrosion problems under aerobic conditions. Desirable limit for drinking water is $150 \mathrm{mg} / \mathrm{L}$. Groundwater present in igneous or metamorphic rocks contains less than $100 \mathrm{ppm}$ sulphate [3]. The sulphate content of atmospheric precipitation is only about 2 ppm, but a wide range in sulphate content in groundwater is made possible through oxidation, precipitation, solution and concentration, as the water traverses through rocks. In sulphide mineralization zones, solution of other sulphide minerals like chalcopyrite, sphalerite, etc. can be induced by ferric sulphate [1]. The reaction equations are given below.

$$
\begin{aligned}
& \mathrm{CuFeS}_{2}+2 \mathrm{Fe}_{2}\left(\mathrm{SO}_{4}\right)_{3} \rightarrow \mathrm{CuSO}_{4} \\
&+5 \mathrm{FeSO}_{4}+2 \mathrm{~S} \\
& \mathrm{ZnS}+4 \mathrm{Fe}_{2}\left(\mathrm{SO}_{4}\right)_{3}+4 \mathrm{H}_{2} \mathrm{O} \rightarrow \mathrm{ZnSO}_{4} \\
&+8 \mathrm{FeSO}_{4}+4 \mathrm{H}_{2} \mathrm{SO}_{4}
\end{aligned}
$$


At ordinary temperature the sulphate of calcium can be dissolved in water up to a concentration of about $1500 \mathrm{ppm}$. Water contains chiefly magnesium and sodium, but little calcium may attain sulphate concentration exceeding 100,000 ppm and even up to $200,000 \mathrm{ppm}$ in certain types of magnesium brines [6]. Reduction of sulphate by bacteria and precipitation of gypsum may cause removal of sulphate in groundwater. Reduction of sulphate by bacteria is the main cause of hydrogen sulphide gas emanating from groundwater in association with lignite and coal.

\subsection{Total alkalinity}

Table 3: Variation of total alkalinity in different sites at different seasons

\begin{tabular}{|l|l|c|c|c|c|c|c|c|}
\hline Year & Season & S1 & S2 & S3 & S4 & S5 & S6 & S7 \\
\hline \multirow{3}{*}{2013} & winter & 110 & 120 & 34 & 282 & 230 & 98 & 211 \\
\cline { 2 - 10 } & summer & 112 & 116 & 32 & 262 & 230 & 95 & 210 \\
\cline { 2 - 10 } & rainy & 120 & 115 & 23 & 275 & 234 & 102 & 212 \\
\hline \multirow{3}{*}{2014} & winter & 121 & 124 & 25 & 265 & 232 & 111 & 213 \\
\cline { 2 - 9 } & summer & 116 & 123 & 26 & 256 & 219 & 112 & 216 \\
\cline { 2 - 10 } & rainy & 114 & 120 & 28 & 264 & 222 & 102 & 220 \\
\hline \multirow{3}{*}{2015} & winter & 35 & 128 & 172 & 234 & 160 & 150 & 98 \\
\cline { 2 - 5 } & 30 & 125 & 154 & 236 & 170 & 145 & 96 \\
\cline { 2 - 9 } & suiny & 32.5 & 142 & 156 & 252 & 165 & 146 & 98 \\
\hline \multirow{3}{*}{2016} & winter & 32 & 125 & 165 & 252 & 174 & 149 & 95 \\
\cline { 2 - 4 } & 36 & 135 & 145 & 245 & 169 & 148 & 97 \\
\cline { 2 - 9 } & rainy & 42 & 136 & 139 & 233 & 152 & 152 & 102 \\
\hline
\end{tabular}

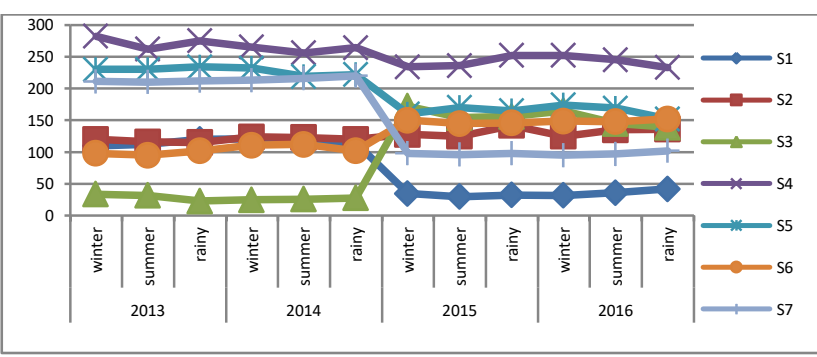

Figure 3: Variation of Total alkalinity with time in different sites at different seasons

The Alkalinity of water is a measure of its capacity to neutralize acids. Alkalinity values provide guidance in applying proper doses of chemicals in water and wastewater treatment processes particularly in coagulation, softening and operational control of anaerobic digestion. The Alkalinity in natural water is caused by bicarbonates, carbonates and hydroxides and can be ranked in order of their association with high $\mathrm{pH}$ values. However, bicarbonates represent the major form since they are formed in considerable amounts due to the action of carbonates with the basic materials in the soil. In the present study Phenolphthalein Alkalinity was absent in all samples and methyl orange alkalinity was ranged from 23.0 $\mathrm{mg} / \mathrm{l}$ to $282 \mathrm{mg} / \mathrm{l}$, this indicates the absence of hydroxyl and carbonate alkalinity and presence of bicarbonate. However, the desirable limit for total alkalinity is $200 \mathrm{mg} / \mathrm{l}$ (BIS). The value of total alkalinity exceeded the limit in the water samples of (S4) Thirupudaimarthur, (S5) Tirunelveli, (S7) Authoor.

\subsection{Hardness}

In this present study, the value of hardness is measured from 53 to $347 \mathrm{mg} / \mathrm{l}$. The highest value 347 was recorded during 2016 on summer at site $S_{3}$ and lowest value 53 was recorded on 2014 during winter at site $S_{2}$. During summer, high level of hardness is present in the water because of dry weather, quantity of water level is lessso the concentration of ion is more and also less water floating. This hardness may affect the photosynthesis and aquatic ecosystem. In rainy season, hardness is very low due to rainfall and more water floating.

Table 4: Seasonal variation of Hardness at station 17

\begin{tabular}{|c|l|c|c|c|c|c|c|c|}
\hline Year & season & S1 & S2 & S3 & S4 & S5 & S6 & S7 \\
\hline \multirow{3}{*}{2013} & winter & 98 & 56 & 66 & 189 & 275 & 115 & 120 \\
\cline { 2 - 9 } & summer & 102 & 59 & 66 & 145 & 270 & 120 & 126 \\
\hline & rainy & 118 & 57 & 78 & 190 & 265 & 140 & 125 \\
\hline \multirow{3}{*}{2014} & winter & 110 & 59 & 75 & 190 & 260 & 100 & 124 \\
\cline { 2 - 9 } & summer & 104 & 56 & 320 & 312 & 255 & 110 & 124 \\
\cline { 2 - 9 } & rainy & 107 & 53 & 78 & 170 & 258 & 115 & 125 \\
\hline \multirow{3}{*}{2015} & winter & 80 & 142 & 99.6 & 120 & 80 & 140 & 185 \\
\cline { 2 - 8 } & summer & 83 & 140 & 94 & 113 & 84 & 135 & 180 \\
\cline { 2 - 8 } & rainy & 83 & 138 & 120 & 111 & 94 & 136 & 185 \\
\hline \multirow{3}{*}{2016} & winter & 86 & 136 & 97 & 112 & 73 & 135 & 187 \\
\cline { 2 - 4 } & 86 & 135 & 347 & 330 & 87 & 136 & 185 \\
\cline { 2 - 8 } & rainy & 83 & 143 & 117 & 107 & 110 & 136 & 187 \\
\hline
\end{tabular}

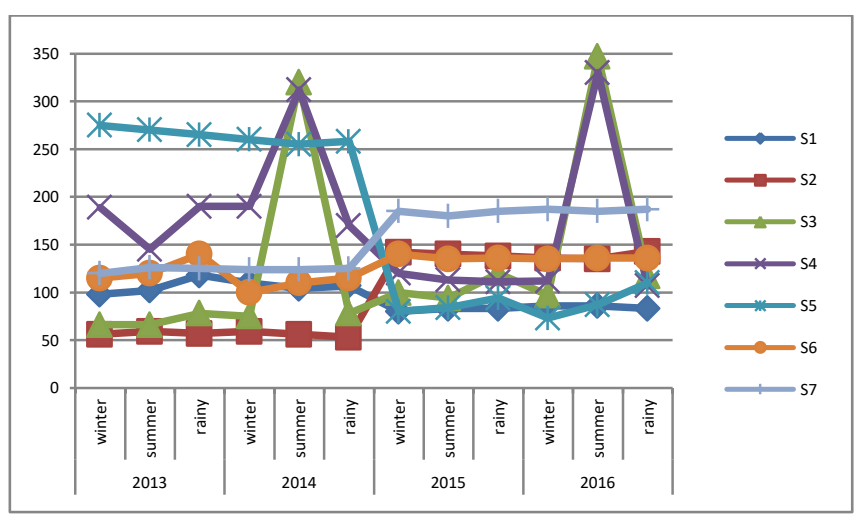

Figure 4: Seasonal variation of hardness at station 1- 7 
Carbonate rocks are the chief source of calcium in natural water and on global scale they contribute $80 \%$ or more of the calcium in streams. Normally Silicate minerals are not soluble in water. But weathering breaks them down into soluble calcium products and clay minerals. Silicate mineral groups like plagioclase, pyroxene and amphibole among igneous and metamorphic rocks and limestone, dolomite and gypsum among sedimentary rocks are the main source of calcium in ground water.

Table 5: Variation of calcium in different sites at different seasons

\begin{tabular}{|c|l|c|c|c|c|c|c|c|}
\hline year & Season & S1 & S2 & S3 & S4 & S5 & S6 & S7 \\
\hline \multirow{3}{*}{2013} & Winter & 28 & 15 & 20 & 80 & 28 & 12 & 32 \\
\cline { 2 - 9 } & summer & 34 & 16 & 19 & 79 & 32 & 14 & 32 \\
\cline { 2 - 9 } & Rainy & 28 & 17 & 20 & 72 & 34 & 16 & 31 \\
\hline \multirow{3}{*}{2014} & Winter & 23 & 12 & 16.4 & 70 & 27 & 13 & 30 \\
\cline { 2 - 9 } & summer & 26 & 14 & 75 & 67 & 29 & 7 & 32 \\
\cline { 2 - 9 } & Rainy & 32 & 16 & 15 & 72 & 24 & 10 & 32 \\
\hline \multirow{3}{*}{2015} & Winter & 18 & 16.2 & 40 & 19 & 21 & 35 & 36 \\
\cline { 2 - 9 } & summer & 20 & 16 & 28 & 33 & 20.5 & 36 & 35 \\
\cline { 2 - 9 } & Rainy & 16.5 & 14.9 & 32 & 29 & 21.5 & 34 & 30 \\
\hline \multirow{3}{*}{$\mathbf{2 0 1 6}$} & Winter & 19 & 18 & 24 & 35 & 14 & 32 & 42 \\
\cline { 2 - 9 } & summer & 20 & 15.6 & 72 & 76 & 16 & 35 & 42 \\
\cline { 2 - 9 } & Rainy & 15 & 15 & 28 & 24 & 33 & 36 & 46 \\
\hline
\end{tabular}

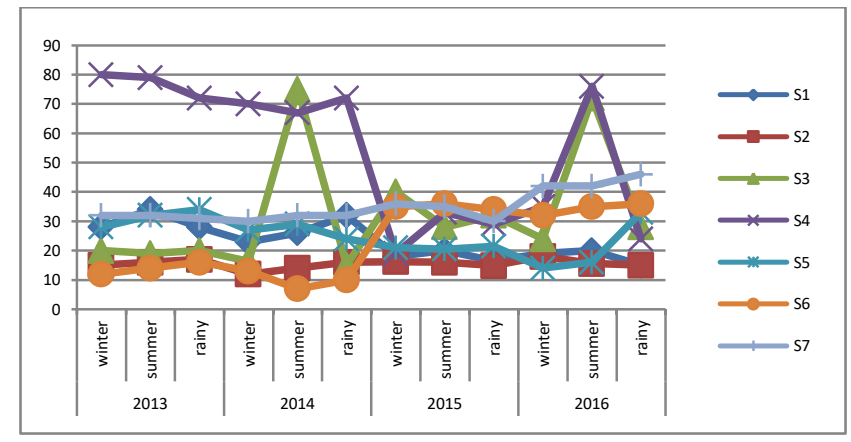

Figure 5: Variation of Calcium with time in different sites at different seasons

The carbonates and sulphates of calcium however, are soluble in water. Due to its abundance in most of the rocks and its solubility, calcium is present almost everywhere in groundwater. In the presence of water containing carbon dioxide in dissolved form calcium carbonate is quite soluble, the reaction being broadly as given in equation.

$\mathrm{CaCO}_{3}+\mathrm{H}_{2} \mathrm{O}+\mathrm{CO}_{2} \rightarrow \mathrm{Ca}\left(\mathrm{HCO}_{3}\right)_{2}$

Calcium carbonate continues to dissolve as long as there is carbonic acid in the water, but precipitation of calcium carbonate may occur once the acid is used up. The causes for the precipitation of calcium carbonate from water are evaporation, increase in temperature, decrease in pressure and $\mathrm{pH}$ beyond 8.2. Calcium cations $\left(\mathrm{Ca}^{2+}\right)$ and calcium salts are among the most commonly encountered substances in natural waters, ranging from zero to several hundred milligrams per liter depending on the source. Calcium often is the most abundant cation in river water. Calcium leads to poor lathering, deterioration of clothes, incrustation in pipes and scale formation. The Calcium content in the study area ranges from 32 to $78.4 \mathrm{mg} / \mathrm{L}$ in aquifer, 13 to $78.7 \mathrm{mg} / \mathrm{L}$ in tube well and from 5.1 to $12.20 \mathrm{mg} / \mathrm{L}$ in pond water. The concentration of Calcium varied from 7 to $80 \mathrm{mg} / \mathrm{l}$. All the samples were within the permissible limit i.e. $75 \mathrm{mg} / \mathrm{l}$ for Calcium (ICMR) in all seasons except the samples of $\left(\mathrm{S}_{4}\right)$ Thirupudaimaruthur.

\subsection{Magnesium}

Magnesium leads to poor lathering, deterioration of clothes, incrustation in pipes and laxative effect as sulphate. The concentration of Magnesium varied from 9.0 to $65.0 \mathrm{mg} / 1$. Mica from intensive weathering of 71 mafia rocks and from pyroxene and amphiboles give rise to silicates. All the samples were within the permissible limit. i.e. $50 \mathrm{mg} / \mathrm{l}$ for Magnesium (ICMR) in all seasons except the samples of Tirunelveli $\left(\mathrm{S}_{5}\right)$.

Table 6: Variation of magnesium in different sites at different seasons

\begin{tabular}{|c|l|c|c|c|c|c|c|c|}
\hline Year & Season & S1 & S2 & S3 & S4 & S5 & S6 & S7 \\
\hline \multirow{3}{*}{2013} & Winter & 15 & 9.9 & 11 & 26 & 60 & 25 & 21 \\
\cline { 2 - 9 } & Summer & 18 & 10 & 11 & 16 & 58 & 26 & 22.8 \\
\cline { 2 - 9 } & Rainy & 21 & 9 & 16 & 28 & 57 & 30 & 22.8 \\
\hline \multirow{3}{*}{$\mathbf{2 0 1 4}$} & Winter & 21 & 9 & 14.2 & 29 & 59 & 21 & 22.8 \\
\cline { 2 - 9 } & Summer & 19 & 10 & 30 & 32 & 60 & 25 & 22.3 \\
\cline { 2 - 9 } & Rainy & 18 & 10 & 15 & 23 & 65 & 27 & 22.5 \\
\hline \multirow{3}{*}{$\mathbf{2 0 1 5}$} & Winter & 15 & 30 & 14 & 24 & 14 & 25.5 & 36 \\
\cline { 2 - 9 } & Summer & 15 & 30 & 18 & 19 & 15 & 24 & 35 \\
\cline { 2 - 9 } & Rainy & 16 & 28 & 21 & 19 & 18 & 24 & 37.6 \\
\hline \multirow{3}{*}{$\mathbf{2 0 1 6}$} & Winter & 16 & 28 & 18 & 18 & 14 & 25 & 35 \\
\cline { 2 - 4 } & 16 & 29 & 34 & 38 & 17 & 24 & 34.7 \\
\cline { 2 - 5 } & 16.5 & 31 & 22 & 20 & 19 & 24 & 34 \\
\hline
\end{tabular}

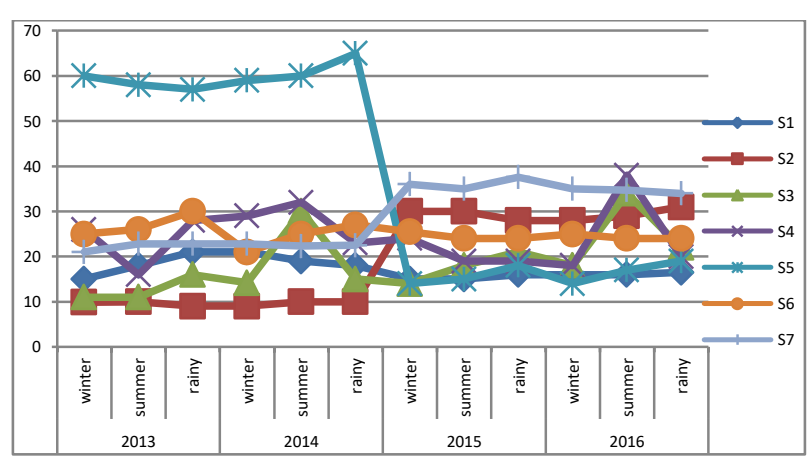

Figure 6: Variation of Magnesium with time in different sites at different seasons

In aquifer $\mathrm{Mg}$ varies from 0.5 to $9.5 \mathrm{mg} / \mathrm{L}$ but in tube or bore well it is from 0.7 to $5.2 \mathrm{mg} / \mathrm{L}$, while in 
pond water it is of 0.65 to $5.6 \mathrm{mg} / \mathrm{L}$. In groundwater the magnesium is derived part from silicates and part from magnesium calcite or dolomite. The weathering of igneous and metamorphic rocks gives rise to soluble carbonates, clay and silica. In the presence of carbonic acid in water magnesium carbonate is converted into more soluble, bicarbonate.

\section{Conclusion}

The primary production varied from season to season with the load of nutrient in addition to phytoplankton species. Water quality parameters affected the primary production in different seasons; The physicochemical characteristics of river water in the study area suggested that Tamirabarani River is contaminated by various effluents. If proper measures are taken for the treatment of sewage before discharge and restrictions are put on various anthropogenic activities upstream, the estuary would remain healthy in the long run. Organic enrichment and higher bacteriological content of the river system determines the quality of the river water. In conclusion, water quality of the upstream areas of the river Tamirabarani was worsening because of higher cations and anions of the study area when compared with the water quality standards WHO [19], BIS [2], and Indian Council of Medical Research. When the salt concentration is increased, it is difficult for plants to extract water. Chlorides are more toxic to some plants. Hardness is due to presence of Calcium, Magnesium, Bicarbonate and Chloride ions.

\section{Reference}

[1] A. Bateman, "Economic Mineral Deposits", Asia Publishing, New York, pp.788, 1960.

[2] BIS (Bureau of Indian Standards), 2012. "specification for drinking water" IS 10500:2012, New Delhi, India.

[3] Davis, Dewiest "Hydrology", John Wiley, New York, pp.463, 1966.

[4] Gyawali, "The improvement of water quality monitoring system on U-Tapao river basin, Thailand", TIChF International Conference (Paper Code es 103),2011.

[5] S.Hema, S.Muthalagi "Mass balance approach for assessment of pollution load in the Tamiraparani river", Int. J. Chem. Tech. Res, 1(2), 385-389, 2009.

[6] J.D. Hem, "Study and interpretation of the chemical characteristics of natural water",
USGS Water Supply Paper, 1473, pp. 363, 1970.

[7] Horne, Ralph Albert, 1978."The chemistry of our environment."

[8] PR Kannel, et al. "Application of water quality indeces and dissolved oxygen as indicators for river classification and urban impact assessment". Environmental Monitoring and Assessment; 132: 93-110, 2007.

[9] B. Lawrence, "Eutrophication status of Thamirabarani River at Kuzhithurai", Journal of Basic and Applied Science, 4(3) p(168173), 2010.

[10] E.O. Lawson. "Physico-chemical parameters and heavy metal contents of water from the mangroves swamps of logos lagoon, logos, Nigeria", advances in biological research, 5(1)08-21, 2011.

[11] A.G. Murugesan, Environmental status of the perennial river Tamirabarani with special reference to domestic and industrial pollution. In Proceedings of Workshop on enhancing the public awareness on the ecological and environmental status of the river basins 2000; 15-20.

[12] A.G Murugesan, et al. "Water Quality Profile of the Perennial River Tamirabarani". Indian Journal of Environmental Protection 1994; 14(8): 567-572.

[13] A. G. Murugesan, K. Mophin Kani "Determination of water quality deterioration using coliforms as pollution indicators at river Tamirabarani", Tamil Nadu, India. Journal of Basic and Applied Biology, 4(1and2): 209215, 2010.

[14] A. G. Murugesan, K. Mophin Kani "Evaluation and classification of water quality of Perennial river Tamirabarani through aggregation of water quality index". International Journal of Environmental Protection 2011; 1(5); 24-33.

[15] A.G Murugesan, et al. "Toxic impact of Environmental Pollutants on Freshwater Habitats" - An overview. Ecology of polluted waters (Ed. Arvind Kumar) Ashish Publishing Corp, New Delhi, India 2002; 1207-1218.

[16] A.G Murugesan, et al. "Pollution status of perennial river Tamirabarani with special reference to sewage mixing and coliform bacteria". Management of sustainable environment 2004; 187-195.

[17] A. J. Stuart, Tinnevelly District Manual, Madras, 1871, p. 1. 
[18] S. Umamaheswari "Water quality assessment of River Thamirabarani at Ambasamudram". Journal of Ecotoxicology and Environmental Monitoring, 14(4):273-276, 2004.

[19] WHO. "Guidelines for drinking water quality", 3rd ed. Geneva: WHO 2004.

[20] C. Subba Rao, N.V. Subba Rao., Groundwater quality in a residential colony, Indian journal of environmental health, 37(4), pp 295-300, (1995).

[21] APHA (2005) Standard methods for the examination of water and waste water $21 \mathrm{st}$ edition, American Public Health Association, Washington, Dc.,USA. 